\title{
In a democracy, what makes an external self-determination claim reasonable? Some reflections on the moral aspect of the question
}

¿En democracia, qué hace que una autodeterminación externa sea una reivindicación razonable? Algunas reflexiones sobre el aspecto moral de esta cuestión

Joan Vergés Gifra

University of Girona

\begin{abstract}
The central part of this article deals with the morality of secession. We present the three main "pure" theories about the morality of secession and suggest the greatest justifying power of an "impure" or mixed theory. At the same time, however, we advocate the need for a proper understanding of the question of the morality of secession. More specifically, we suggest that the best way to raise it is by introducing the notion of "reasonableness" into the question itself.

KEY WORDS Secession; External Self-Determination; Morality;

Reasonableness.

RESUMEN La parte central de este artículo versa sobre la moralidad de la secesión. Exponemos las tres principales teorías "puras" sobre la moralidad de la secesión y sugerimos la mayor potencia justificativa de una teoría "impura" o mixta. Sin embargo, al mismo tiempo defendemos la necesidad de entender adecuadamente la cuestión acerca de la moralidad de la secesión. Más concretamente, sugerimos que la mejor manera de plantearla es introduciendo la noción de "razonabilidad" en la misma pregunta.
\end{abstract}

PALABRAS CLAVE secesión; autodeterminación externa; moralidad; razonabilidad.

RECIBIDO RECEIVED

$17 / 10 / 2020$ 


\section{APROBADO APPROVED \\ $12 / 12 / 2020$ \\ PUBLICADO PUBLISHED \\ $30 / 1 / 2021$}

\section{NOTE OF THE AUTHOR}

Joan Vergés Gifra. Ferrater Mora Chair of Contemporary Thought, Faculty of Arts, Department of Philosophy, University of Girona.

Traducción y actualización del artículo La nació necessària [The necessary nation].

Address: Facultat de Lletres. Pça. Ferrater Mora, 1. 17004 Girona

E-mail: joan.verges@udg.edu

ORCID: 0000-0002-1901-298X 
A number of political processes have come to put in serious difficulty Western states whose democratic regimes appear to be well established. I refer mainly to the cases of Quebec in Canada, Scotland in the United Kingdom, and the Basque Country and Catalonia in Spain. Each of these processes has its own particularities, of course. And different have been the approaches taken by each of the central governments of these countries in order to confront or respond to the demands for self-determination: tolerating the possibility of secession and legislating on it (Canada), negotiating a binding referendum on independence (United Kingdom), systematically denying the possibility of any constitutional reform and repressing the possibility of any type of consultation (Spain). In view of such diversity, one may ask: "What attitude is more appropriate? What attitude should a democratic government have in the face of such demands? The relevance of the question is obvious, especially if we consider the Canadian example. Let us recall that in the face of the very narrow result against secession in the second consultation in 1995, the Canadian federal government asked the country's Supreme Court three questions: according to the Canadian Constitution, can Quebec unilaterally leave the federation?; does international law recognize Quebec's right to unilaterally become independent from Canada?; if there is a conflict between Canadian domestic law and international law, which should prevail? As it is well known, the Supreme Court responded negatively to the first two questions and, consequently, the third one became irrelevant. However, in its reflections, the Court added a comment that has had great significance both for Canadian policy and for the debate on the morality of secession in general: if in a province of the federation there is "a clear majority" in favour of secession in answer to a "clear question" concerning secession, then the Canadian government will have a duty to negotiate the possible secession of the province. And the reason for this, according to the Court, is that the text of the Canadian Constitution is inspired by the following four principles: (a) constitutionalism and the rule of law, (b) democracy, (c) federalism, (d) protection of minority rights.

When trying to justify the policies of the Spanish government on this issue, of course, one can always state that the constitutional doctrine in Spain is different from that of Canada and Great Britain. And surely it is different from them, especially after the Basque and Catalan episodes of the last fifteen years. The question, however, is whether such an answer can really satisfy someone who sincerely supports the democratic ideal rather than a rude version of legal positivism. The response of the Canadian Supreme Court to which we have just referred shows that there are two extremes to be avoided here: the opinion of 
those who maintain that in a democracy any secession is always unfounded and illegitimate (Arteta, 2015); the position of those who maintain that these kinds of problems - the problems of the demos- are unsolvable from a democratic point of view (Dahl, 1991). In fact, everything suggests that these types of questions are relevant to the democratic quality of a country ${ }^{1}$. If democratic theory, understood in a broad sense, were incapable of (1) indicating under which circumstances reasonable claims for secession by a sector of the population occur and (2) what response is most appropriate in such cases, then democratic theory would be much less attractive. In democracy, political legitimacy has something to do not only with the fact that people recognize that certain institutions are sources of effective authority, but with the fact that they recognize themselves -to put it with Rawls- as self-authenticating sources of valid claims. In democracy everyone is a subject before the law. But what is specific to the democratic ideal is that there might exist constituent periods where any subject can aspire to act as a citizen in a radical sense.

In what follows, we will touch upon a fundamental part of the question (1) just mentioned: in what circumstances, within a democratic framework, will a claim for external self-determination or secession be reasonable? To be more precise, we are going to focus on one of the central aspects that must be taken into account when determining the reasonableness of this type of petition, namely, the reasons of a "moral" nature. Thus, we will not address the question (2) and, consequently, we will not be able to offer a complete picture of the problem and its possible treatment either ${ }^{2}$. Until now, most of the discussions that have taken place on the problem of the morality of secession (i) have been in terms of the moral right of a population to selfdetermine itself externally, (ii) have assumed that the process of secession would take place unilaterally, and (iii) the entire burden of proof has fallen on the secessionist side. However, it is likely that approaching the issue in these terms has created no small amount of confusion. For in a consolidated democratic context, (i) the issue of moral rights seems less pressing, (ii) there is little gain in focusing only on the claims of the pro-independence sector, and (iii) the scenario of unilateral, non-negotiated secession is unlikely. In

1 According to the Democracy Index issued by The Economist in 2018 the Spanish government's attempt to forcibly stop the illegal referendum on independence from Catalonia on October 1 [2017] and the repressive treatment of pro-independence politicians threatened to turn Spain into a defective democracy. See: https://www.eiu.com/n/democracy-index-2018/

$2 \mathrm{~A}$ very commendable attempt in this direction is the recent initiative led by Eusko Ikaskuntza - Sociedad de Estudios Vascos "Territorial Conflicts of Sovereignty in Europe: Good Practices and Proposals for Resolution" (See http://www.eusko-ikaskuntza.eus/en/projects/territorialconflicts-of-sovereignty-in-europe-good-practices-and-proposals-for-resolution/pr-58/). 
our opinion, raising the issue as we believe it should be done, that is, in terms of reasonableness would help avoid the possible misunderstandings that these three assumptions easily generate. Speaking of the reasonableness of a claim for external self-determination helps us to think that (i) it is not just a matter of "rights" or "morality" in an excessively limited sense of the term, but that there is a whole set of considerations to be taken into account; that (ii) claims for self-determination have to be made in good faith with a view to what would be acceptable to the rest of the population and, correspondingly, the institutions of the parent state should be willing to recognize the strength of such claims; that (iii) it is not a unilateral process, but rather one that presupposes the possibility of a certain consensus among the parties. We will return briefly to these points in the last section.

\section{Three "pure" theories on the morality of secession and an "impure" one ${ }^{3}$}

There is a certain amount of consensus in the literature that three basic arguments or theories exist in favour of secession: the remedial theory of secession, the plebiscite theory and the theory of national self-determination. We could call them "pure" because each one of them is deployed as having sufficient force to morally justify secession.

\section{First: The Plebiscite theory}

The plebiscite theory is characterised by the aim to establish a direct connection between fundamental democratic values and the reasonableness of secession. The same principles that justify the governance of society as a whole by a majority also legitimise the decision by the majority in a territory to build a new state. Theorists in favour of a plebiscite tend to differ somewhat on the precise nature of the democratic argument justifying secession. However, most of them coincide in including the condition of viability on both sides: if the new state and the old state are viable, it is contrary to the spirit of democracy not to allow the secession.

Harry Beran, one of the first authors to deal with the issue in the 1980s, argues that secession must be permitted if it is "desired by a territorially concentrated group within a state and is morally and practically possible." (Beran, 1984, p. 23) He bases his argument on reasons of freedom and sovereignty, and on the principle of the rule of the majority. According to Beran, liberal democracy assumes that people have the capacity to make decisions about their own lives and have a fundamental desire to exercise

3 This section is partially based on a former text which appeared in Vergés Gifra (2014). 
this capacity. He contends that democratic sovereignty essentially consists of the moral right of individuals to decide which political relations they wish to maintain among themselves. Therefore, if we consider that democratic sovereignty lies in the citizens of a society, we must also acknowledge their right to form new sovereign political entities. Democracy should have no fears about acknowledging this right, since it has a procedure that enables the peaceful resolution of disputes, namely majority rule. In democracy, the boundaries of jurisdictional units should be determined solely through the application of this rule. Otherwise, the boundaries of states will be morally arbitrary or simply immoral. Christopher Wellman makes a similar argument to that of Beran (Wellman, 2005). A group in a territory has the right to secession simply by virtue of its right to political association, provided it is viable; that is, provided that the state it forms can carry out the legitimating functions of a state, and that its severing of the territory from the existing state will not impair the latter's ability to carry out effectively those same legitimating functions. The right to political association is based on the value we assign to people's autonomy. A democratic state cannot affirm that its citizens are morally autonomous and at the same time tell them that they cannot be politically self-governing. Unless we wish to argue that democracy has a merely instrumental value, we must acknowledge the right to secession as an inextricable part of the right to political association which is intrinsic to it. In general, those who defend the possibility of establishing a conceptual distinction between the right to decide and the right to self-determination adhere to this argumentative strategy (González Bondía et al., 2015; Queralt et al., 2014; Cagiao et al., 2016).

The plebiscite theory initially seems very appealing because it bases the right to secession on that which apparently strengthens the legitimacy of the democratic state: the consent or will of citizens. In this respect, we might find it just as attractive as the classical social contract theories of Locke, Rousseau or Kant. However, appearances can be deceptive. To think that the secession issue can be solved through the classical idea of the social contract is to misunderstand what social contract theory sets out to do. Social contract theory does not aim to explain what justifies the existence of one particular state or political society. In fact, neither does it aim to establish that the best political regime is a democracy. The sole purpose of social contract theory is to explain what justifies the existence of political authority within a state. None of the classical proponents of social contract theory addressed the issue of secession.

Indeed, as Buchanan argues, it is likely that the error of the plebiscite theory is its failure to realise the difference between jurisdictional authority, 
meta-jurisdictional authority and private property. Wherever there is jurisdiction, there is jurisdictional authority; that is, "a domain of legal rules and, derivatively, a sphere of authority for the agency or agencies that make, adjudicate, and enforce those rules." (Buchanan, 2003, p. 232) Jurisdiction is therefore synonymous with territory. A territory is a geographically determined jurisdiction. It is not merely a piece of land. A piece of land may be the private property of an individual or group of people. Meanwhile, jurisdictional authority (the capacity to make, adjudicate and enforce legal rules) cannot lie exclusively with landowners but rather with the population as a whole. Citizens are the ultimate repository of political authority, not property owners. Unfortunately, this distinction, so fundamental to our democracies, sometimes seems to be forgotten (in fact, neoliberalism consists of an attempt to blur this distinction). However, it is very important to bear it in mind. In fact, those who own private property do so by virtue of the private property laws established by the jurisdictional authority. Furthermore, political or jurisdictional authority is not the same thing as meta-jurisdictional authority: jurisdictional authority consists of making, adjudicating and enforcing laws in a particular territory, while meta-jurisdictional authority grants the right to determine the boundaries of a territory and the consequent existence of a jurisdiction. According to Buchanan, proponents of the plebiscite theory would commit a fallacy by uncritically applying categories which are valid in one regulatory sphere (the jurisdictional one) in a different sphere (the metajurisdictional one). Buchanan is clear about attributing the right to secession only to those groups who have suffered severe injustices and not to groups who may simply have jurisdictional authority.

The importance of not confusing these different types of authority is perceived when we focus on the types of problem encountered by those in favour of the plebiscite theory. "A group has the right to secede if it democratically decides to do so, by means of a vote," they say. To which opponents reply: "Do you realise what the consequences of turning this into a principle would be? Are you aware of how much instability there would be in the world? Well, all right, let's accept your position. The immediate problem is to determine which group has this right. Who should be entitled to vote: only the citizens of the territory where the plebiscite is called for, or all the citizens in the state? It's obvious that a secession would affect all of them. So why should only the citizens of the territory in question be able to vote?" To which the advocates of the plebiscite theory counter: "Living in a state is like being in a marriage. When one of the parties wishes to leave, he or she leaves. There's no need to ask the other party for permission. A secession is like a divorce." The divorce 
metaphor is quite common in the literature and debates (Buchanan 1991; Bauböck, 1999). However, their opponents reply: "Understood. But if it's so crucial for people to live in the country where they want to live and for them to be able to decide whether they get married or divorced, then those in favour of independence must surely agree that in electoral districts where the majority of citizens vote against independence, they must be allowed to remain within the parent state. It wouldn't make sense for the right claimed for some to be denied to others." And they add: "But that's not the only issue. They'll also have to accept that, at any time in the future, whenever part of the population of the future state wishes to vote for its own independence or to be reincorporated in the former parent state, then it must surely be allowed to do so, and regardless of its motives. For example, if a group of rich people decides to purchase part of the territory, settles there and then requests a referendum to vote on the creation of a Republic of the Rich, those in favour of the original independence vote must surely allow this new group to vote on its own independence. Perhaps this group of rich people has done the maths and realised that it is better off becoming independent than remaining part of the new state. And if that is what these people want, what arguments can be used against them? Maybe they will raise the possibility of secession as a negotiating strategy in order to achieve a privileged position within the state; that is, they will blackmail the state with the possibility of secession. But what could be said to dissuade them, if that is what they want?".

In short, the most important problems encountered by those in favour of the plebiscite theory are (i) the definition of the demos (who has the right to take part?), (ii) the instability that may be generated (both domestically and abroad), (iii) negative consequences for social justice, mainly due to the possibility of minority group using its own demands for secession in order to blackmail a majority group.

One might assert that the advocates of the plebiscite theory are wrong on two counts. First of all, they seem to make the mistake of assuming that the principle of majority rule is sufficient to explain the legitimacy of a secession process. It is true that, in a democracy, political legitimacy ultimately lies with the will of the majority of citizens. A democracy cannot function if it systematically goes against the will of the majority of people. Nonetheless, majority rule is not enough to determine the framework, the political unit in which a majority can exist. Majority rule becomes a principle of democratic legitimacy when all the problems involved in a secession process have been tackled. So, on first examination, the problem is conceptual: the majority of whom? In other words, in order to discuss majorities and minorities, it is 
first necessary to determine the framework that encompasses them. However, a secession process precisely involves creating a framework in which, from a certain moment, there will be new majorities and new minorities. Meanwhile, the problem with placing the entire focus on the principle of the majority is also pragmatic: when we govern ourselves solely by the principle of the majority, stability issues immediately arise, since majorities depend on the frameworks that mark them out and, moreover, are changeable.

The second mistake that proponents of the plebiscite account make is to refuse to explain the set of reasons that might justify a secession. They make no attempt to address the question of why people wish to secede. They simply state the fact that this is what people want. They argue that, similarly to what occurs in a normal democracy, where the reason for voting for one political option or another is of no consequence, in a secession process people's reasons for wanting independence must also be irrelevant. That is why, as we have seen, it opens the door to blackmail by secessionist groups or to negative consequences for social justice. The basic point here is that for a democracy to be fair it is not enough to simply take into account the wishes or wills of the people. No doubt, the preferences of the people are central. But, as Charles Taylor pointed out some years ago, what makes a preference count morally is not the mere fact that someone has it, but the fact that such a person holds a "strong evaluation" with respect to what he or she values as a good, in the sense of constituting a norm for desire (Taylor, 1981). It is necessary, therefore, that the will be based on adequate reasons. From a slightly different perspective, Rawls stressed a similar point when he argued "the priority of the right over the good" (Rawls, 1999, p. 28).

The only explanation for why advocates of the plebiscite theory make the mistakes we've referred to is that they already have a reasonable idea of which political unit should be asked whether it wishes to stay or leave. Perhaps without being aware of it, they are more or less clear about the fact that certain groups can legitimately raise a claim for secession, while other groups cannot (it makes no sense and is not acceptable for a group of rich people to do so, for example). It is not that political will is not relevant in itself. The problem lies in knowing who the relevant political entity is in such matters and what reasons would constitute acceptable grounds for requesting secession.

\section{Second: The Remedial Theory}

The theory of the remedial right to secession is presented as a particular version of the right to rebel. Just as people have the right to rise up against tyranny, a group of people in a state who are systematically treated unfairly by 
its government also have the right to rebel and create a new state. However, Allen Buchanan, the leading proponent of this type of theory, adds that this right depends on two conditions. Firstly, the group must be located in a territory where it represents the majority of the population and, secondly, secession must really be the only way to put an end to the injustice suffered by the group. Secession constitutes a remedy of last resort: once all the possible solutions for putting an end to the injustice have been attempted and have proved unsuccessful, the last resort available to the group is to leave.

The version we have of this theory depends on the injustices on which we focus our attention. In other words, depending on what we consider to be an intolerable injustice, we will have one version of the theory or another. Buchanan argues that a group has the right to secede in six specific cases. When (i) the physical survival of the group's members is threatened by the actions of the state (for example, in the case of the Kurds in Iraq under Saddam Hussein's rule); when (ii) the group in question had its own legitimate state in the recent past and it was illegally seized by the present-day parent state (such as in the case of the republics of Estonia, Latvia and Lithuania, which regained sovereignty in 1991). A group would also have the right to secession when (iii) after having enjoyed a significant level of political autonomy, which the group wishes to preserve, the state unjustifiably withdraws this autonomy (such as when Milosevic revoked Kosovo's autonomy at a stroke in 1989). When (iv) the people of a territory are discriminated by "taxation schemes, or regulatory policies or economic programs that systematically work to the disadvantage of some groups, while benefiting others, in morally arbitrary ways" (Buchanan, 1991, p. 40), then the group in question also has the right to secession (according to Buchanan, this was the main reason why the thirteen North American colonies seceded from the British Empire). Furthermore, a group is entitled to secede when (v) the parent state becomes a failed state and the policy of "every man for himself" takes root, or when (vi) the state systematically refuses to engage, in good faith, in negotiations concerning well-intentioned requests for autonomy made by a territorial group. ${ }^{4}$

Does the remedial theory of secession fare any better in comparison with the plebiscite theory? In principle, it does. At the very least, it does not

4 Buchanan introduced this final reason for the first time at a public lecture in Barcelona on 14 May 2014, entitled "The Strongest Case for Catalan Independence", organised by the Olof Palme International Foundation, based in Barcelona. He followed the same line of argument in his talk at the Ateneu Barcelonès on 4 October 2018. According to Buchanan "at most and depending on how the relevant facts are interpreted" conditions (iii) and (vi) apply in the case of Catalonia. So, there are reasons for sustaining a unilateral moral right to secede in the case of Catalonia but comparatively speaking it is not "the strongest sort of case" (See Buchanan, 2018). 
seem to be affected by some of the problems that undermine the plebiscite theory. It adequately distinguishes the concepts of authority and, furthermore, sets out criteria for identifying which groups are entitled to become fully sovereign political entities. Indeed, the criterion of being an unjustly treated group considerably limits the number of groups that can claim the right to secession. According to Buchanan, this is one of the main advantages of the theory. One advantage of the remedial theory is that it first of all addresses the issue of reasons and through the answer it gives to that question aims to solve the problem of which entities have the right to secede.

Nevertheless, it also has significant problems. We will highlight three. For a start, it seems to be based on a questionable assumption. It assumes that the immense majority (if not all) secession processes involve a high level of violence. Buchanan often refers to the ethnic conflicts that occurred in the Balkans in the 1990s. This explains his staunch defence of the principle of territorial integrity, since he considers that only this principle can guarantee, on the one hand, the security of individuals and, on the other hand, the right incentives for them to cooperate with each other The idea here is that if it were so easy to secede and leave, groups would often rather leave than attempt to work out their differences with the rest of the people (Buchanan 1997, pp. 46-47; Hirschman 1970). Given the assumption that secession processes are generally violent, it is understandable that the moral requirements should be rather demanding. Nonetheless, not all secession processes are violent. There was no violence, for example, in the case of Norway and Sweden, or in that of the Czech Republic and Slovakia; neither there was violence in Québec or Scotland or on the side of Catalan independentists.

In other words, in the same way that it is virtually impossible for the armed struggle of a secessionist group to succeed (the failures of the IRA and ETA are significant in this respect), globalisation and international law make it increasingly unlikely for secession attempts to be put down militarily. Therefore, the idea that the requirements for justifying a secession must be very demanding is weakened. Indeed, Buchanan accepts that the splitting of Czechoslovakia, for example, was perfectly proper and led to the creation of two legitimate political entities. In other words, he takes no issue with consensual secessions because the split or secession is agreed and because there is no violence. He thereby demonstrates that the condition of being of a group that has suffered severe injustice is not necessary in certain cases, particularly when both parties accept the holding of a referendum.

However, this being the case, why should any territory with prosovereignty or pro-secession majorities not aspire to the same thing? This brings 
us to the question of whether the refusal by a central government to organise or allow a referendum on secession when a certain territory repeatedly requests one constitutes a major injustice. This highlights the second type of problem with this theory, namely the meaning of the concept of justice put forward by Buchanan, which is presented as neutral and should therefore help to settle the dispute. He holds that "a perfectly just state (...) is one which does not violate relatively uncontroversial individual moral rights, including above all human rights, and which does not engage in uncontroversially discriminatory policies toward minorities." (1997, p. 40) Buchanan explicitly states that the definition of injustice cannot include the fact that a state "contains a minority people or nation (...) or a majority that seeks to secede but has not been permitted to do so." (1997, p. 41) Therefore, neither can it be considered unjust that a minority nation wishes to gain independence but cannot because it is prevented from doing so. As we have said, Buchanan holds that this meaning of justice is minimal and can be accepted by any theorist of secession, yet given the implication that we have seen above, it seems impossible for it to be acceptable to supporters of national self-determination (a third theory which we will consider below). In fact, national self-determination approaches typically argue that to deny a people the right to self-determination (and in certain circumstances to secession) constitutes a major injustice.

The criticism that can perhaps be levelled at Buchanan is in fact that he does not properly characterise the idea of nation (Miller 2003, p. 269). In fact, he conceives it apolitically. He argues that the existence of a political will for self-government is not a necessary part of the idea of nation. By way of example, he states that "What makes a group a nation or people is the fact that it has a common culture, history, language, a sense of its own distinctiveness, and perhaps a shared aspiration for constituting its own political unit." (Buchanan 1997, p. 38, our italics) $)^{5}$ This undoubtedly explains why he does not consider it an injustice that a nation is denied the right to secede if its members have not suffered severe injustices. Nevertheless, it is necessary to have a limited conception of justice in order to defend this argument, one that precisely excludes the issues and claims normally raised by the members of a nation when they are striving to gain full sovereignty. It is possible that Buchanan holds a notion of justice in the broad distributive justice tradition; that is, a notion that includes not only the distribution of wealth but also that of individual rights and opportunities when no problems exist regarding the demos. However, in addition to distributive justice understood in this sense,

5 Furthermore, in other places he seems to suggest that the concept of "people" or "nation" cannot be satisfactorily defined (see Buchanan, 1991, p. 49). 
there are other forms of justice. There is also, for example, the kind of justice which Charles Taylor identified as "recognition" (1994) or what Philippe van Parijs has recently termed "justice as parity of esteem" (Van Parijs 2011, p. $119)^{6}$. This type of justice is not directly related to the attribution of individual rights or even to the distribution of opportunities and wealth. It has nothing to do with civil rights, political rights or socio-economic rights. It concerns the way in which a society recognises that certain individuals form part of certain collectives for whom it is vital to be recognised as such. The failure of a society to encourage or provide this recognition constitutes a lack of respect to the individuals of these collectives, undermining their dignity.

For example, women and gay men do not wish to merely have the same formal rights as heterosexual men. They want public recognition (in a variety of ways, often controversial) that they form part of society. What they are demanding is to be visible and accepted as they conceive of themselves. That is the only way to put an end to the type of discrimination or stigmatisation to which they have historically been subjected. As such, they consider that this demand must be understood in terms of justice. Something similar occurs with a substantial number of the demands of communities with secessionist aspirations, such as Quebec or Catalonia. The members of these communities do not simply wish to have the same rights or the same formal opportunities as the rest of society. They want recognition that they form part of a community distinct from others and, therefore, recognition of the rights associated with this status. And they perceive the refusal to grant them this recognition as an injustice.

A third problem with the remedial theory is that when it comes to identifying groups entitled to secession, it does not suffice to say that they must have suffered or be suffering injustices. As we have just explained above, justice is a broad term; various kinds of justice exist, one of which is justice in recognition. This means that the identification of acts of injustice will depend directly on a group's perception of its own collective identity. As such, the existence of injustices will depend on the prior existence of a group of people with a collective conscience who demand equal respect as members of this group. Some of these groups (such as gays and women) will

6 According to van Parijs, "a just society (...) is not only one whose institutions organize cooperation and distribute opportunities (...) there is a dimension of equal respect that is irreducible to the equalization of opportunities (...) It is certainly possible for such stigmatization [due to belonging to a certain group] to affect opportunities, either directly through discrimination or indirectly by depressing people's self-esteem and self-confidence, and thereby their capacity to seize whatever opportunities are formally open to them. But whether or not it does, it violates justice as equal respect." (Van Parijs 2011, p. 119). 
not define themselves as such in relation to a territory, but other groups (such as nations) will. The hunch here is that groups of this sort are the collectives that proponents of the remedial theory of secession have in mind in order for the theory to work. In order to determine whether there has been a group which has suffered an injustice, it is first of all necessary to determine whether such a group existed with the possibility of suffering significant injustices in this respect. Buchanan himself seems to realise this. For example, when he discusses distributive injustice (which is what the North American colonists adduced to justify their struggle for independence), he acknowledges that the sense of grievance in a group will depend on whether the group believes that it forms an identity or not; that is, "whether it [the group] regards those to whom some of its resources are being transferred by government redistribution policies as its own people or as an alien group." (Buchanan 1991, p. 51)

As we have already explained, Buchanan holds that the people in a territory have the right to demand independence if their territory was seized in the past by the government of the present-day parent state. However, this begs the question "Why should it want to reclaim it?" Let us imagine that the new state (the one created through the annexation of the territory) has ended up becoming a reasonably just state, according to the parameters of the theory. In such a case, we can imagine that someone who has followed Buchanan's line of reasoning might say, "The people who formed part of that previous sovereign state are now integrated in the new state and are formally treated in the same way as the other citizens of the new state. They are equal citizens with the same rights and opportunities. Why should it be taken into consideration that in the past, dozens of years ago, two or three generations belonged to another state? It is true that they were full citizens in the original state. But this is also the case in the new state. Moreover, they are better off in a large state than in a small one. So what would be the good of demanding that this historical injustice be redressed in the form of a new state? Why not just let bygones be bygones? What's the point of stirring up old wounds?" The remedial theory of secession does not seem capable of answering these questions.

\section{Third: The theory of national self-determination}

According to this theory, groups that qualify as nations possess a prima facie moral right to secession. By virtue of its nation status, a group may leave the state to which it has belonged until now and determine itself as a fully sovereign entity. The nation in question may have suffered injustices or abuse, but the right to secession does not primarily depend on this circumstance. It primarily depends on its nation status. This is what legitimises the right and, if certain conditions arise, justifies embarking on a secession process. 
How can nation status justify the reasonableness of their claims for secession? When it comes to answering this question (concerning the grounds for the right to secession), we realise that there are in fact two slightly different versions of the argument. On the one hand, we have an argument which we could call the "argument of individual interest". On the other hand, we have what we could call the "democratic argument". These two arguments are complementary rather than contradictory. However, each has its own line of reasoning, which is why we are keen to differentiate them.

The argument of individual interest. The way the world is today, belonging to a nation is a very important matter for individuals. Their wellbeing, including their personal self-esteem, depends on whether the national community to which they belong prospers as such. But in order for that to be possible, the community in question must have a certain amount of recognition and a certain amount of political autonomy. When a national community is denied this recognition and autonomy, it sees its prosperity as a group in jeopardy. The community in question then has the right to demand full political autonomy. However, it will also have this right if there is not a serious problem of recognition but rather a "legitimate interest" in prospering as a nation (based on the fundamental interest of its members) and the community concludes that it will not be able to satisfy this interest by remaining in the parent state.

The key here is the close relationship established between belonging to a nation (that is, national identity) and the interest of the individuals who compose it. Logically, the right to self-determination does not belong to individuals but rather to the group. However, it is based on the interests of individuals that arise as a result of their belonging to the group. In this respect, we can see why authors state that the argument is an instrumental one.

As such, according to Raz and Margalit (1994), nations are a kind of "encompassing group". These groups have two main characteristics. First of all, they are characterised by having pervasive cultures. This means that the points of view, judgements, tastes and life projects of individuals are strongly influenced by the group culture. Furthermore, whether we perceive something as an opportunity depends on how we have been educated and on the culture in which we have grown up. The second main characteristic is that the fact of being a member of an encompassing group (or nation) is crucial for the identity of individuals since it provides an anchor. Some individuals will be better equipped than others to make the most of the opportunities that come their way, but it is virtually impossible to lose one's status as the member of a group, not even by committing crimes. Belonging to a group does not depend 
on personal success but rather on contingent and accidental circumstances such as having grown up in a particular place or having lived there for many years. That is why if a group is scorned or denigrated, the individuals who belong to it also feel scorned or denigrated; their self-esteem is affected. These two main characteristics of a nation explain why individuals are so keen to preserve it. According to Raz and Margalit, the interest of individuals in their own well-being and in the prosperity of the group is, therefore, "among the most vital human interests". The fortunes of the group profoundly affect the well-being of individuals. The reasonableness of a claim for self-determination as an independent state therefore comes into play when the members of a nation reach the conclusion that the best (or only) way to guarantee respect and enjoy the associated gain in well-being is through full self-government.

The democratic argument, on the other hand, does not depend so much on establishing an intrinsic relationship between belonging to the nation and the basic interests of individuals but rather on making it clear that, given the circumstances today, a real connection exists between democracy and nation. It is evident and almost tautological, as Miller notes, that a nation has sound reasons for wanting to hold self-government, either partially or totally (Miller, 1995, p. 90). It is when a nation has self-government that it expresses itself clearly as such, as a community that wishes to govern itself. Having a state can also better satisfy the concomitant moral obligations of the national community and better protect its national culture.

What is not so clear, perhaps, is why a self-governing political unit (a democratic state, for example) and a nation should coincide. The answer given by the proponent of this theory, as we have explained, is that there is no intrinsic need for them to coincide, but when they do the democratic regime functions more smoothly and the outcome is more positive. As John Stuart Mill said in Considerations on Representative Government (1861/2010) a democracy only functions well if the citizens who live there trust each other and think that they have mutual obligations. In other words, if the political community is also a community of solidarity. Trust and the feeling of having mutual obligations are fundamental in democracy, far more so than in any other type of regime. They are essential elements when it comes to solving collective action problems. But it is also an essential factor in order for the redistribution of wealth to occur or for the deliberative ideal to be satisfied.

The theory of national self-determination has been the subject of significant criticism. Two objections are particularly notorious. First, the difficulty of characterizing a group as a nation or what Margaret Moore (1997) has called "the indeterminacy problem". What is a nation? Since Ernest Renan 
(1992) tried to answer that question in his famous lecture at the Sorbonne on 11th March 1882 there have been hundreds of attempts to satisfactorily define what a nation is through subjective or objective, constructivist or primordialist criteria. The most poisoned discussion does not take place in the academia though, but in courts and parliaments. It is there where real issues are at stake, since it is always a matter of political discussion which groups qualifies as a nation. The outcome of the discussion is crucial because of the connection between being considered a nation and having an intrinsic right to self-determination -internal or external ${ }^{7}$. According to Moore the problem is easily surmountable if we stick to a subjective definition of nation, that is if we understand that "a nation refers to a group of people who identify themselves as belonging to a particular nation group, who are usually ensconced on a particular historical territory, and who have a sense of affinity to people sharing that identity" (Moore 1997, p. 905). However, the problem seems thornier if we pay attention to the fact of mixed identities, that is, to the fact that an individual might identify herself with more than one nation at the same time. So, for example, a person in Montreal might feel just as Canadian as Quebecois, or a person in Barcelona might consider herself just as Spanish as Catalan. The problem here is not only about the difficulty of characterizing in national terms the people living in a territory where the fact of mixed identities is common. The problem has mainly to do with the appropriateness of forcing people to vote in exclusionary terms either for one nation or the other -if the issue is between two different national identifications.

A second criticism has to do with instability. "Doesn't the theory of self-determination have the same defect as the plebiscite theory, in that it will generate a huge amount of political instability in the world if we take it literally? There are many more nations in the world than states!" Moreover, disputes over national issues are often fierce, full of emotion and, as history shows, it is not difficult for them to end in irrational confrontations. Defendants of the theory therefore are in need to prove again that nationalism can be tamed. Indeed they have been warned about this criticism and two possible responses are available to them. The first is to stipulate some fairly restrictive conditions which must be fulfilled in order for a nation to be authorised to secede. The second is to highlight the need for states that include more than one nation to become multinational federations in order to accommodate the legitimate

7 The Spanish Constitution defines Spain as "Nation" (capital letters) and, instead, speaks of "nationalities" (in lower case) to refer to national minorities, unspecified (article 2). On the other hand, in his Ruling 31/2010 -for many analysts, the spark that set fire to the situation and led to the Catalan sovereigntist process- the Constitutional Court ruled that the description made in the Catalan Statute of Catalonia as a "historical reality" had no legal or political relevance. 
demands of each of the groups. The two responses are obviously not mutually exclusive. Kymlicka (2001) tends to place the emphasis on the second one. His hope is that, in many cases, the demands of national minorities can be accommodated within multinational states. Miller, on the other hand, places the emphasis on the first response. He holds that in order for a nation to be authorized to secede it must first fulfil six conditions (Miller 1995, p. 113). Firstly, the creation of a new state must be the only alternative which the group considers essential in order to remain a nation. Secondly, it is necessary that the territory for which secession is demanded does not contain minorities whose own identities are incompatible with the creation of the new state. Thirdly, consideration must be given to the situation of individuals who would like to continue living in the parent state and who, nevertheless, remain in the seceding territory. Fourthly, the new state must be viable, in terms of securing itself territorially. Fifthly, the parent state must not be radically weakened by the secession. Finally, the new state must not take with it natural resources that are vital for the parent state. Pau Bossacoma (2020) has argued in a similar vein for the need of "complementary causes".

\section{Fourth: Against purism: the mixed argument}

We might consider the three theories seen above as "pure" theories on the morality of secession. In this article we do not discuss the question of which line of argument is superior. We have limited ourselves to showing its virtues and problems. Each author tends to adopt one or the other theory. Now, there is no need to stay with just one of them. There is no need to be a purist. Unless they consider internally that only their approach is valid the three are perfectly complementary to each other. We might even think that the defects of one can be covered by the virtues of another. Certainly, each of these theories is presented as providing sufficient normative force to justify the full reasonableness of a petition for secession, but that does not prevent the best argument one can make for a process of external self-determination from being, in reality, of a mixed nature.

Allan Patten has put forward a powerful argument along these lines. (Patten, 2014, chapter 7) In our view he has tried to complement the national self-determination theory with the plebiscite theory and the remedial approach. According to Patten, a nation has a reasonable claim to secession when the parent state does not recognise it as such. The crux of the matter is the failure of political recognition; that is, a failure of recognition of the fact that the members of a national community wish to govern themselves. It is not merely a question of a lack of "cultural" recognition (possibility of expressing themselves in their own language, recognition of the folklore and customs 
of the territory, etc.). One way of satisfying the demand for recognition is to make the state a multinational one (which may include measures of a symbolic nature and giving national minorities their own voice in foreign policy). When it can be affirmed that a multinational state has granted sufficient recognition to the national minorities of which it is composed, these minorities cannot then secede. But if the state has not granted sufficient recognition to a national minority that originates an injustice which in due time and under certain conditions can lead to an external self-determination process. Some years before Patten, Josep Costa put forward a very similar approach (Costa, 2003).

In fact, if we look at the public debates on the issue that have taken place in Quebec, Scotland, the Basque Country or Catalonia, the defense of the reasonableness of the request for external self-determination formulated by their main institutions almost never takes place in terms of just one of these theories. Most of the time, the supporters of secession resort to each of these pure theories: they put at stake the fact of being a nation next to a series of claims for justice and, based on that, they postulate the need to ask the population of this region about the possibility of changing the type of constitutional relationship with the parent state. Perhaps, in the arguments issued by the pro-secession institutions, the remedialist argument has had less weight, sometimes almost imperceptible (Scotland). This may be due to the fact that in a democratic context the injustices suffered by the secessionist minority are not as scandalous as in similar processes where there is no consolidated democratic context. This does not mean, however, that having been victims of injustices in the past does not play an important role in the considerations of the minority in question in order to consider itself a nation or to have come to the conviction that it is better to become independent and thus explicit a desire for full self-government. We should not exclude the possibility that a certain type of reasons (the reasons of justice, for example), in some cases (for example, in a democratic context) have one weight and in others (for example, in a non-democratic context), another. Theories about the morality of secession, so to speak, do not walk alone. And with this we come to the concluding remarks.

\section{Final remarks}

In the central part of this article we have set out the three pure theories on the morality of secession, pointing out their strengths and also their weaknesses. Finally, we have suggested that, possibly, from a moral perspective, the best 
way to defend the reasonableness of a petition for external self-determination is not by adopting a pure approach, but an impure or mixed approach.

Before concluding, however, I would like to make a couple of comments on the type of theoretical activity we have carried out and thus take up again some of the initial observations with which we started this article. In the introduction, we argued that the relevant and important question is about the reasonableness of a claim for external self-determination. When the discussion takes place only in terms of moral rights, it is not uncommon for confusion to occur. First of all, it is not strange that one confuses the right to secession understood as a liberty (liberty-right in Hohfeld's terminology, 2001) with the right to secession understood as claim-right. Kosovo might have the right (liberty) to become unilaterally independent from Serbia, but this does not mean that Serbia is obliged to recognize Kosovo as a sovereign state. On the other hand, when the debate takes place in terms of right it is easy to confuse the discourse in favour of the right to secession with the discourse in favour of undertaking a process of independence. To speak of rights is not exactly to speak of reasonableness. Even less so when we circumscribe the debate to the moral right. In contrast, the discourse on reasonability is much broader. Talking about the reasonability of a petition for secession helps us see that there are more reasons to take into account, besides the moral reasons. We warned earlier that there is no need to be purist in seeking moral reasons for secession. Now we should say that there is no need to be monistic when it comes to arguing for the reasonableness of a process of external self-determination.

What other kinds of reasons do I mean? I think we could distinguish at least four types of reasons: moral reasons, ethical reasons, political-legal reasons, and existential reasons. There is no room for an adequate characterization of each of these reasons. But if I had to do it anyway (i) for moral reasons we could mean above all the kind of reasons about what we owe to each other as human beings when we are ready to be assessed in terms of rightness or fairness. Thus, from this point of view, as persons, when certain conditions (specified by the theories on the morality of secession) are met, it is necessary to recognize that a certain demand for external self-determination is reasonable and has to be met. (b) By ethical reasons, I am referring specifically to that set of considerations about what is good that an individual considers relevant by virtue of her more or less conscious adherence to a certain comprehensive doctrine or to a certain shared project about how one should live. (c) The field of political-legal reasons is possibly the broadest of all and would include, of course, the whole set of considerations related to the various branches of law, but also all questions related to politics in a broad sense, economic aspects, and so on. (d) By existential 
reasons I mean those issues that a subject would consider relevant when, in his opinion, his own personality or identity is at stake.

Each of these reasons has -to put it with Wittgenstein- a different grammar and a different kind of force. Moral and ethical reasons, for instance, do not usually respond in the first place to prudential approaches, unlike political-legal reasons. The latter usually respond to conditional or feasibility factors. Moral reasons, on the other hand, are presented with a special forcefulness -they seem to be valid for any case in similar circumstances and for any reason- and contrast notably with the reasons of an existential nature, which can be featured as fragile (Canto-Sperber, 2001). In any case, it is evident that these reasons accompany each other and even closely overlap. Possessing a moral reason in favor of something, for example, can notably affect reasons of an ethical, political-legal or existential character. Likewise, reasons of a political-legal nature can affect in some way (increase, decrease, even annul) the strength of moral reasons. The fact that a morally legitimate secession may affect the standard of living or the ethical or existential project of the citizens in the new state may even nullify the opportunity to assert the relevant moral reasons. In our opinion, this type of considerations has not been given sufficient attention until now. In some approaches (e.g., Bossacoma 2020, Buchanan 1991, Norman 2006) a so-called "institutional" approach has been adopted in which attempts are made to combine mainly moral reasons with political-legal ones. Nonetheless, the discussion on the moral aspect of the issue has predominated in the literature. This has led to the rise of criticism of moralism or idealism against what we have called pure theories (Sanjaume, 2019). Raising the issue in terms of reasonableness could help to broaden the normative approach and thus contribute to a better understanding of a complex issue that current democratic theory cannot ignore.

\section{Bibliographical References}

Arteta, Mikel (2015). Por qué es antidemocrática la secesión [Why secession is antidemocratic]. Revista de Filosofia, 40:1, 157-180. DOI: https:// doi.org/10.5209/rev_RESF.2015.v40.n1.48444

Bauböck, Rainer (1999). Why Secession is not like divorce. In K. Goldman et al. (eds.), Nationalism and Internationalism in the Post-Cold-War Era. UCL.

Beran, Harry (1984). A Liberal Theory of Secession, Political Studies, 32:1. 21-31. DOI: https://doi.org/10.1111/j.1467-9248.1984.tb00163.x 
Bossacoma, Pau (2020). Morality and Legality of Secession: A Theory of National Self-Determination. Palgrave MacMillan.

Buchanan, Allen (1991). Secession: The Morality of Political Divorce from Fort Sumter to Lithuania and Quebec. Westview.

Buchanan, Allen (1997). Theories of Secession, Philosophy and Public Affairs, vol. 26/1. 31 - 61. DOI: https://doi.org/10.1111/j.1088-4963.1997. tb00049.x

Buchanan, Allen (2003). The Making and Unmaking of Boundaries: What Liberalism has to Say, in Allen Buchanan \& Margaret Moore (eds.), States, Nations and Borders. Cambridge University.

Buchanan, Allen (2018). The strongest case for Catalan independence. Public lecture at the Ateneu Barcelonès, Barcelona, 16 October https://www.youtube.com/watch?v=dXK82J7q4II\&ab_ channel=AteneuBarcelon\%C3\%A8s).

Cagiao y Conde, Jorge y Ferraiuolo, Gennaro (Eds.) (2016). El encaje constitucional del derecho a decidir [The constitutional fit or the right to decide]. Catarata.

Canto-Sperber, Monique (2001). L'inquiétude morale et la vie humaine [The moral unawareness and the human life]. Presses Universitaires de France.

Costa, Josep (2003). On Theories of Secession: Minorities, Majorities and the Multinational State. CRISPP, 6:2, 63-90. DOI: https://doi.org/1 $0.1080 / 13698230510001702763$

Dahl, Robert (1991). Democracy and its critics. Yale University.

Eusko Ikaskuntza - Sociedad de Estudios Vascos (2020) Territorial Conflicts of Sovereignty in Europe: Good Practices and Proposals for Resolution. http://www.eusko-ikaskuntza.eus/en/projects/territorialconflicts-of-sovereignty-in-europe-good-practices-and-proposals-forresolution/pr-58/

Gobierno de España (1978) Constitución española [Spanish Constitution].

Documentos del BOE (https://boe.es/legislacion/documentos/ ConstitucionCASTELLANO.pdf)

González Bondía, Alfonso; López, Jaume; Vilajosana, Josep María; Barceló, Mercè; y Corretja, Mercè (2015). El derecho a decidir: teoría y práctica de un nuevo derecho [The right to decide. Theory and Practice of a new right]. Atelier.

Hirschman, Albert O. (1970). Exit, Voice and Loyalty. Harvard University. 
Hohfeld, Wesley (2001). Fundamental Legal Conceptions as Applied in Judicial Reasoning. Aldershot.

Kymlicka, Will. (2001). Politics in the Vernacular. Oxford UP.

Mill, John Stuart (2010). Considerations on Representative Government.

Oxford University. (First publication in 1861).

Miller, David (1995). On Nationality. Oxford University.

Miller, David (2003). Liberalism and Boundaries: A Response to Allen Buchanan. In A. Buchanan \& M. Moore (eds.) States, Nations and Borders. Cambridge UP.

Moore, Margaret (1997). On National-Self-determination. Political Studies, XLV, 900-913. DOI: https://doi.org/10.1111/1467-9248.00118

Norman, Wayne (2006). Negotiating Nationalism. Oxford University.

Parijs, Philippe. van (2011). Linguistic Justice for Europe and for the World.

Oxford University.

Patten, Allan (2014). Equal Recognition. Princeton University.

Pogge, Thomas (2002). World Poverty and Human Rights. Polity.

Queralt, Joan; Ridao, Joan; Pons, Xavier; Torno, Joaquín; Giménez-Salinas, Esther; Font, Antoni; González Bondía, Alfonso y Sagarra Eduard (2014). ¿Existe el derecho a decidir? Preguntas y respuestas sobre el proceso abierto en Cataluña. [There is a right to decide? Questions and answers about the open process in Catalonia]. Tibidabo.

Rawls, John (1999). A Theory of Justice: revised edition. The Belknap Press.

Raz Joseph y Margalit, Avishai (1994). National Self-Determination, in J. Raz. (Ed.) Ethics in the Public Domain. Clarendon.

Renan, Ernest (1992). Qu'est-ce qu'une nation? [What it is a nation?] PressesPocket.

Sanjaume, Marc. (2019). Moralism in theories of secession: a realist perspective. Nations and Nationalism, DOI: https://doi.org/10.1111/ nana.12412

Taylor, Charles (1981). Social Theory as Practice. Oxford University.

Taylor, Charles (1994). The Politics of Recognition, in Charles Taylor (et al.) Multiculturalism. Princeton University.

The Economist (2018). Democracy Index. https://www.eiu.com/n/ democracy-index-2018/

Tribunal Constitucional (2010). Sentencia 31/2010, de 28 de junio, en relación con diversos preceptos de la Ley Orgánica 6/2006, de 19 de 
julio, de reforma del Estatuto de Autonomía de Cataluña. https://www. parlament.cat/document/intrade/218218

Vergés Gifra, Joan (2014). La nació necessària [The necessary nation]. Angle.

Vilajosana, Josep (2014). Principi democràtic i justificació del dret a decidir.

[Democratic principles and justification of the right to decide] Revista d'Estudis Autonòmics i Federals, 19.

Wellman, Cristopher (2005). A Theory of Secession. Cambridge University. 